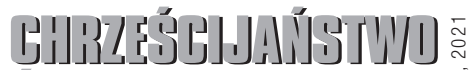

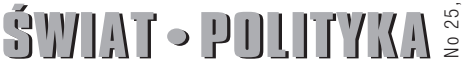

ZESZYTY SPOŁECZNEJ MYŚLI KOŚCIOŁA

\author{
Ks. Bruno-Marie Duffe
}

Dykasteria ds. Integralnego Rozwoju Człowieka, Watykan

\section{Przyjąć innego, przyjąć Boga, przyjąć Boga w innym. Podejście teologiczne i etyczne do gościnności wzajemnej}

\begin{abstract}
Abstrakt: Zjawisko migracji stając się coraz częstszym doświadczeniem Europy i świata jest nie tylko kwestią czysto polityczną czy społeczną, ale dla chrześcijan jest także istotnym zagadnieniem o charakterze etycznym i teologicznym. Autor podejmuje analizę etycznych i teologicznych aspektów migracji, w tym także kwestię prawa/obowiązku gościnności.
\end{abstract}

Słowa kluczowe: Kościół, migracja, integracja

Abstract: The phenomenon of migration, becoming an increasingly frequent experience of Europe and the world, is not only a purely political or social issue, but for Christians it is also an important ethical and theological issue. The author analyzes the ethical and theological aspects of migration, including the issue of the right / duty of hospitality.

Keywords: Church, migration, integration

\section{Wstęp}

Gdy rozważamy wezwania w Prawie biblijnym, będącym jednocześnie rdzeniem Ewangelii, do chwalenia Boga (pierwsze przykazanie) i poszanowania godności innych ludzi (drugie przykazanie), stanowi to dużą trudność zarówno dla Żydów, jak i dla społeczności chrześcijańskiej. Mimo że wspólne odwołanie do Abrahama, ojca wiernych, przesiedleńca wędrującego do Ziemi Obiecanej, ma zasadnicze znaczenie dla naszej pamięci... Mimo że pierwsze doświadczenie Jezusa jako 
dziecka to doświadczenie wędrowca przemieszczającego się z Egiptu w pierwszych miesiącach swego ludzkiego życia... Nie ma pewności, czy duchowe i moralne zadanie przyjęcia swego brata i wędrowca uznawane jest przez wszystkich chrześcijan za praktyczny wyraz wiary. Gościnność i miłość, z jaką traktowani są ludzie w potrzebie zgodnie z zasadami prawa Mojżeszowego, nauczania proroków, nauki głoszonej przez Jezusa Chrystusa, to zarówno dziśs, jak i w przeszłości duchowe wezwanie do nawrócenia. Może nas wzruszać Ewangelia, a jednocześnie może się zdarzyć, że odmówimy innemu człowiekowi, przybywającemu do nas i zaburzającemu nam rytm życia, jak to się zdarzyło przyjacielowi goszczącemu nieoczekiwanie o północy (Łk 11,5). Możemy zanosić do Boga Ojca modlitwy o ochronę, a jednocześnie zamykać drzwi migrantom proszącym o ochronę nas. W pierwszym Liście św. Jana czytamy: „Jeśliby ktoś posiadał majętność tego świata i widział, że brat jego cierpi niedostatek, a zamknął przed nim swe serce, jak może trwać w nim miłość Boga?” (1 J 3, 17).

Główna teza teologiczna stawiana $\mathrm{w}$ tym podejściu polega na przyjęciu tego pojawiającego się paradoksu pomiędzy miłością Bożą a miłością bliźniego, który nigdy nie jest antagonizmem pomiędzy miłością duchową a ludzką, gdy rozpoznajemy Boga w innym człowieku z jego bezbronnością. Przyjąć oznacza najpierw spojrzeć na drugiego - mężczyznę, kobietę, dziecko czy starca. Jest to doświadczenie fizyczne i duchowe, w którym troska angażuje troskę drugiej osoby. Rozpoznanie Boga w bliźnim, w wyjątkowym doświadczeniu wzajemnych odwiedzin i gościnności, poszerza samo znaczenie gościnności. Pamiętamy nadto Ewangelię wg św. Mateusza, rozdział 25, w której znajdziemy trzy przypowieści: o dziesięciu pannach, o talentach i o sądzie ostatecznym. Na sądzie tym Król identyfikuje się z ubogimi, z przybyszami, z cierpiącymi i z więźniami: „Wszystko, co uczyniliście jednemu z tych braci moich najmniejszych, Mnieście uczynili” (Mt 25, 40).

\section{Chrześcijańskie podejście teologiczne jako środek do społecznego zrozumie- nia gościnności i solidarności}

Jak myśleć wspólnie, jak przyjmować i jak wierzyć, zważywszy na naszą wspólną pamięć, współczesne myślenie o społeczeństwie i współczesną wrażliwość?

Jeśli za punkt wyjścia przyjmiemy doświadczenie spotkania z bliźnim, moglibyśmy stwierdzić, że nasze ludzkie doświadczenie odkrywania różnic kulturowych oraz nasze wspólne człowieczeństwo otwiera nas na zrozumienie czegoś, co moglibyśmy nazwać „współczłowieczeństwem”. Koncepcja takiego „współczłowieczeństwa” 
sugeruje coś, z czym eksperymentował sam Jezus, począwszy od dnia swego chrztu - wysoce symbolicznego aktu solidarności z ludźmi i wspólnoty między boskością a człowieczeństwem. Moglibyśmy rzec, że doświadczenie gościnności jest głęboko zakorzenione w sakramencie chrztu: wspólnie zanurzani jesteśmy w tej samej wodzie i wspólnie przechodzimy na drugą stronę rzeki - na stronę sprawiedliwości i miłości, gdzie oczekuje nas Bóg.

Na pierwszym poziomie takiego zaproszenia do analizy teologicznej brane są pod uwagę rozmaite formy troski składające się na doświadczenie spotkania z innymi ludźmi, które wiążą ze sobą odwołanie do wspólnoty w Chrystusie i doświadczenie wzajemnego względu na innych, w naszym współczesnym kontekście. „Troskę” należy tu rozumieć zarówno w aspekcie fizycznym, jak i duchowym. Otoczenie „troską" to w gruncie rzeczy fundamentalne doświadczenie istnienia innego od siebie oraz wspólnej obecności. Moglibyśmy wręcz stwierdzić, że gościnność wzajemna ma swój punkt wyjścia w spojrzeniu na bliźniego i otoczeniu siebie nawzajem troską.

W naszej chrześcijańskiej teologii stworzenia, będącą pamiątką i uczczeniem Bożej troski o życie i o Boże stworzenia, moglibyśmy rzec, że życie istoty ludzkiej ma swe źródło w Bożej trosce. To troska i miłość urzeczywistniają istotę ludzką - mężczyznę i kobietę - zwaną "każdym” i dążącą do osiągnięcia podobieństwa Bogu. W teologii patrystycznej pierwszych wieków chrześcijaństwa czytamy, że Bóg-Stwórca jednocześnie spogląda na człowieka, którego powołał do życia, i na Jezusa Chrystusa, swego umiłowanego Syna, który jest Zbawcą i człowiekiem doskonałym.

Nasz chrzest, w ludzkim doświadczeniu troski, wraz z migrantami i uchodźcami, wiedzie nas ku solidarności i współczuciu, współpracy oraz wspólnocie. Jest to doświadczenie niezwykle głębokie, a niekiedy także trudne. Rozumiemy więc, że niektórzy ludzie raczej odmówią okazania troski. Do tego doświadczenia spotkania i solidarności wzywa każdy: „Czy wierzysz?” i „Jeśli wierzysz, kochaj, a ujrzysz...”

Oczywiście możemy stwierdzić, że często dopadają nas sytuacje nagłe, a ta sytuacja pcha nas na pierwszą linię frontu działań humanitarnych. Tak wiele mamy do zrobienia. I jesteśmy świadomi, że musimy nauczyć się wszystkich prac, jakich wymaga ludzka solidarność: zadbać o ciała, zapewnić dzieciom szkołę, zrozumieć prawo, towarzyszyć w codziennych czynnościach... Wszystkie te działania 
związane są z dobroczynnością i względem na innego człowieka, znajdującego się w stanie przeraźliwej samotności. Znajdujemy się w fazie przejściowej pomiędzy taką samotnością („de-solation”, czyli „wygnaniem z kraju”) a pocieszeniem („con-solation”, czyli „otwarciem na wzajemne uznanie swego istnienia”).

\section{Jezus przemawia do Bartymeusza}

Doświadczenie spotkania pomiędzy Jezusem Chrystusem a ludźmi cierpiącymi czy wygnanymi jest zawsze dialogiem. „Co chcesz, abym ci uczynit?” - pyta Jezus Bartymeusza (Mk 10, 51). Taki dialog otwiera wszystkim drogę do możliwych prób wyrażenia nadziei. Możemy jednak też powiedzieć, że dialog ów stanowi realizację teologicznego paradygmatu przymierza: biblijne, chrześcijańskie przymierze jest dialogiem pomiędzy Bogiem a każdą osobą, a jednocześnie modelem naszego braterstwa w społeczeństwie, które polega na słuchaniu bliźniego i mówieniu do niego, szczególnie gdy człowiek ten czeka na wieści o jego uznaniu i solidarności. Ludzka solidarność, czyli uznanie w bliźnim innego siebie, „równego i potrzebujqcego pomocy", jak rzekł papież Jan Paweł II [Jan Paweł II 1987: 39], musi być oparta na wspólnej trosce, słowach lub obietnicach. Przyjęcie i powitanie polega w pierwszej kolejności na nawiązaniu dialogu, wysłuchaniu historii o cierpieniu i śmierci: o wojnie, nocy, przemycie, strachu, ucieczce, poszukiwaniu nowej nadziei... Na wysłuchaniu historii pogruchotanej, a jednak wciąż ludzkiej. Być wysłuchanym to tak, jakby być przywróconym do życia. Tylko bowiem troska i słuchanie może umieścić doświadczenie przywitania $\mathrm{w}$ dwojakim wymiarze pamięci i nadziei, nie pozwalając jednocześnie na zredukowanie tegoż doświadczenia do samych praktycznych działań czy organizacji pomocy innym. Jesteśmy świadomi, że działalność humanitarna może być wyczerpująca dla wszystkich okazujących solidarność, gdyż jest to praca ponad siły fizyczne i psychiczne.

Wysłuchanie i uznanie to ustanowienie połączenia między przyjmowaniem a zbieraniem, między odkrywaniem a dawaniem. Osoba, którą przyjmujemy i z którą zmierzamy wspólną drogą, znajduje swe miejsce również w naszym umyśle i w naszej modlitwie: możemy się do niej odnieść z imienia, które wymawiamy przed obliczem Boga Ojca. Zbieranie i dawanie to druga strona przyjmowania i witania. Można rzec, że jest to duchowe przejście kształtujące ludzką pamięć.

\section{Gościnność jako dialog nadaje gościnności wzajemnej jej pełny wymiar.}

Gdy Abraham dostrzega trzech ludzi pod dębami Mamre (Rdz. 18), doświadcza spotkania z nieznanym. Nie potrafi nazwać tych ludzi czy też tego człowieka - w tekście bowiem mowa jest o jednej lub trzech osobach: „trzech ludzi” lub 
„o Panie”. „Ujrzawszy ich podążył od wejścia do namiotu na ich spotkanie. A oddawszy im pokłon do ziemi, rzekł: «O Panie, jeśli darzysz mnie życzliwością, racz nie omijać Twego sługi! Przyniosę trochę wody, wy zaś raczcie obmyć sobie nogi, a potem odpocznijcie pod drzewami. Ja zaś pójdę wziąć nieco chleba, abyście się pokrzepili, zanim pójdziecie dalej, skoro przechodzicie koło sługi waszego» (...)" (Rdz. 18, 3-5).

Abraham rozpoznaje w trzech nieznajomych swego Pana i okazuje im troskę. Nie zna ich, gdyż nie potrafi nazwać kraju, do którego wysyła go Pan. Udaje się tam jednak i nie znając tych ludzi, przyjmuje ich, sądząc, że w ich osobach to sam Bóg do niego przychodzi. Gościnność staje się więc łaską, która została mu dana, a on czuje się zaszczycony, że właśnie jego wybrano do przyjęcia gości. Gościnność jest zaszczytem, a Abraham dzieli się wszystkim, co w swym bogactwie ma najlepszego: najczystszą mąką i najmłodszym cielęciem. Przyjęcie jawi się jako wezwanie do dawania. Możemy też powiedzieć, że dawanie oznacza radość przyjmowania. A zatem dla Abrahama gościnność jest doświadczeniem wzajemności. W tym momencie na myśl nam przychodzi złota zasada w Starym i Nowym Testamencie: „Wszystko więc, co byście chcieli, żeby wam ludzie czynili, i wy im czyńcie!” (Mt 7, 12).

Symbolu takiej wzajemnej gościnności upatrywać należy w obietnicy płodności w przyszłości. „O tej porze za rok (...) twoja żona Sara będzie miała wtedy syna” (Rdz. 18, 10). W tym doświadczeniu wzajemnej gościnności przyszłość ponownie otwiera się na dar życia. W tym punkcie naszych rozważań o niezwykłej nadziei migrantów na posiadanie dziecka i inwestowanie w przyszłość jako czas nowych możliwości.

Możemy powiedzieć, że tę samą perspektywę zyskujemy, czytając o odwiedzinach proroka Eliasza u biednej wdowy w Sarepcie, w czasach suszy i ogromnego ubóstwa. Gdy prorok zwraca się do ubogiej kobiety z prośbą o posiłek, ogłasza, że dzban mąki nie wyczerpie się i baryłka oliwy nie opróżni się do dnia łaski obiecanej przez Boga ubogim (anawim: ludzie, którzy nie posiadają majątku, a jedynie wiarę i nadzieję w Bogu).

\section{Nasz Bóg nigdy nie poddaje się rezygnacji i wzywa nas, byśmy korzystali $\mathrm{z}$ naszych rezerw na rzecz dbałości o życie.}

W doświadczeniu wymiany, charakterystycznym dla wzajemnej gościnności, możemy powiedzieć, że jesteśmy zjednoczeni w Boskim projekcie spełnienia i przymierza na rzecz człowieczeństwa i z człowieczeństwem. Zaś wezwanie 
do gościnności reprezentuje naszą część odpowiedzialności w tej opowieści/ historii przymierza - z Bogiem, z Jezusem i pomiędzy nami samymi. Wyzwanie polega nie tylko na tym, aby przetrwać w sytuacji kryzysowej, ale też pozostać i działać z inspiracji błogosławieństwami: Błogosławieniu ubodzy w duchu (...) Błogosławieni, którzy wprowadzają pokój (...) cierpią prześladowanie dla sprawiedliwości, albowiem do nich należy królestwo niebieskie (Mt 5, 1-11).

Dwa główne odniesienia, nad którymi należy się pochylić, łącząc doświadczenie powitania i braterskiego przymierza jako symbolicznego aktu wymiany, to dwa momenty w przebiegu Pasji Jezusa Chrystusa: moment, gdy Jezus umywa nogi swych apostołów i gdy dzieli chleb, który wręcza apostołom: „To jest ciało moje” (J 13, 1 - 20; Mk 14, 22-25). Wspominamy też trzeci tekst, którym Jezus wzywa apostołów do nakarmienia głodnego tłumu: „Wy dajcie im jeść” (Łk 9, 13). Po umyciu apostołom nóg Jezus rzecze: „Czy rozumiecie, co wam uczyniłem? (...) umyłem wam nogi, to i wyście powinni sobie nawzajem umywać nogi” (J 13, 12-15). Jest to nie tylko akt oczyszczenia czy pewien rytuał, ale też doświadczenie wskrzeszenia, zadbania o ludzkość i otwarcia nowego przymierza na przyszłość, na czas przyjścia Boga.

„Przyjmowanie i dawanie” to wspomnienie Chrystusa, który oddał życie - zarówno cielesne, jak i swą miłość - za całą ludzkość, i który wzywa apostołów, aby miłością swą obdarzali każdego, kto przybywa ostatni i którego nogi krępują więzy...

\section{Doświadczenie wzajemnej gościnności jest podstawą i otwarciem wspólnoty przyszłości}

Intuicja przyjęcia bliźniego, szczególnie w osobach migrantów, zmuszonych do opuszczenia swego kraju, rodzin, braci i przyjaciół, przywodzi na myśl wezwanie do przyjęcia Syna Bożego w naszej wspólnocie ludzkiej. Jest to doświadczenie założenia i ponownego założenia Kościoła (jak i wspólnoty społecznej) z udziałem tych mężczyzn i kobiet, dzieci oraz starców. Jezus Chrystus znajduje się w doświadczeniu powitania jako człowiek, który ma być uznany za Syna. Zwrot, którym posłużył się Jezus wysyłający swych apostołów: „Kto przyjmie to dziecko w imię moje, Mnie przyjmuje; a kto Mnie przyjmie, przyjmuje Tego, który Mnie posłał" (Łk 9,48), rozumieć można jako poczucie misji, ale też jako znaczenie doświadczenia samych migrantów. Jest coś w spotkaniu i wzajemnym uznaniu, co dotyczy objawienia i Królestwa Bożego. Rozumiemy, że problem migracji nie jest jedynie kwestią społeczną i polityczną (organizacji czy reorganizacji 
przestrzeni społecznej), ale też teologiczną: nadanie godności to głoszenie wspólnoty w Chrystusie - wspólnoty, w której każda osoba ludzka do Chrystusa należy.

Wiemy, że powołani jesteśmy do połączenia trzech odwołań: powszechnego braterstwa w Chrystusie, misji otrzymanej od Chrystusa oraz wspólnoty ucieleśnionej już przez Chrystusa.

Gdy dzielimy wspólną drogę z migrantami, staje się jasne, że „wyzwaniem” jest wiara wspólna $\mathrm{z}$ nimi oraz wiara w siebie nawzajem, taka, jaką Bóg obdarza nas samych i każdą osobę. Takie wzajemne uznanie jako członków Ciała prowadzi nas ku poświęceniu życia. „(...) chcieliśmy wam dać nie tylko naukę Bożą, lecz nadto dusze nasze, tak bowiem staliście się nam drodzy" (1 Tes 2,8$)$.

Jeśli oprzemy teologię duszpasterską o zasadę godności, wspominamy troskę Bożą o wszystkie stworzenia. A zatem teologia moralna i społeczna oparta o godność pozwala dokonać powiązania pomiędzy stworzeniem, zbawieniem i miłością bliźniego. Niesiemy również życie społeczne w przyszłość. Nie może bowiem istnieć myślenie duszpasterskie bez nadziei, a jeśli ograniczymy myśl społeczną i duszpasterską jedynie do działania, może nas to doprowadzić do wyczerpania, a być może też do utraty ufności.

\section{Prawa człowieka jako wspólne obowiązki}

W 1963 r. w swej encyklice Pacem in terris Jan XXIII napisał, że poszanowanie praw człowieka ma znaczenie dla osoby, której prawa są szanowane; poszanowanie takie budzi w człowieku obowiązek poszanowania praw innych. Dalszy tekst encykliki brzmi: „Gdy zaś zasady współżycia obywateli są formułowane jako prawa i obowiązki, wtedy ludzie pojmują coraz lepiej wartości duchowe i intelektualne, w szczególności zaś rozumieją, czym jest prawda, czym sprawiedliwość, czym miłość, czym wolność, uświadamiają też sobie, że są członkami społeczności, która zakłada te właśnie wartości. Ale to nie wszystko. Ludzie bowiem, zainteresowani tego rodzaju sprawami, dążą do lepszego poznania prawdziwego Boga osobowego i znajdującego się ponad ludzką naturą. Dlatego też stosunek wiążący ich z Bogiem traktują jako podstawę swego życia - tak swego życia wewnętrznego, jak współżycia z innymi ludźmi” [Jan XXIII 1963: 44-45].

\section{Nadzieja dawana nadziei pozbawionym}

W trzeciej części swej „trylogii teologicznej”, której tytuł brzmi „Kościół w mocy Ducha”, współczesny teolog Jürgen Moltmann rzuca pewne światło na zdolność 
przewidywania i nadziei, która stanowi nieodłączną składową oddania własnego życia i która bierze udział w mesjanistycznym pośredniczeniu: „W chrześcijańskiej koncepcji zapośredniczenia mesjanistycznego czasów przyszłych, przewidywanie i opór jednoczą się w ucieleśnieniu nadejścia czasów i oddania siebie. W miejscach, gdzie wolność oczekiwana jest w formie konkretnych wyzwoleń, wyzwolenia te nie mogą być uzasadniane jedynie wtedy, gdy istnieją wyzwolenia innych, nie jako walka o osobiste interesy. Wynika stąd, że konkretne przewidywania przyszłości (zaangażowanie, solidarność, dzielenie się) można wykazać wyłącznie jako oddanie siebie dla przyszłości innych. Prawdziwa nadzieja jest doświadczeniem dawania na rzecz przyszłości ludzi pozbawionych nadziei. Przewidywanie wolności realizowane jest w wyzwoleniu uciśnionych. Wiara okazywana jest w miłości ubogich (...)" [Moltmann 1980: rozdział. 4, pkt 5].

\section{Urzeczywistnienie}

Cztery czasowniki, których używa papież Franciszek w swym orędziu na Światowy Dzień Pokoju (1 stycznia 2018 r.), zapraszają nas do stawienia czoła wyzwaniu, jakim jest wzajemna gościnność w kontekście współczesnych migracji. Te cztery czasowniki, tj. przyjmować, chronić, promować i integrować, kreślą aktywny obraz wzajemnej odpowiedzialności i prowadzą nas do refleksji nad sytuacją ludzkiej społeczności w naszym nowoczesnym (czy ponowoczesnym) świecie [Franciszek 2018].

Przyjmowanie to wzięcie pod uwagę istnienia bliźniego, z jego własną konkretną opowieścią i historią. Jednocześnie polega ono na ponownym przemyśleniu możliwości społeczeństwa ludzi, zarówno w chwili obecnej, jak i na przyszłość. Istotą zagadnienia jest dbałość o życie i o „życie wspólnie”. I wreszcie przyjmowanie polega na otwieraniu nowych możliwości odkrywania i spotykania ludzi. Warunkiem przyjęcia innego jest przezwyciężenie własnego lęku w obliczu nieznajomego. $\mathrm{W}$ naszej perspektywie wzajemnej gościnności przyjmowanie musi być powiązane $\mathrm{z}$ wzajemnością: przyjmujemy siebie nawzajem, z naszymi doświadczeniami, kulturą, pamięcią i wiarą.

Chronienie polega na uznaniu drugiego człowieka za członka naszej własnej rodziny, element tej samej konstrukcji społecznej i duchowej. Jak powiedział członek grupy ds. dialogu izraelsko-palestyńskiego: „Gdy zrozumiemy, że chroniąc drugiego człowieka chronimy samych siebie, znajdziemy się na ścieżce pokoju”. Chronienie to odwołanie się do praw człowieka, które - jak wspomnieliśmy - stanowią ludzki obowiązek międzypokoleniowy, zarówno dziś, jak i jutro. Wiemy, że potrzeba nam zaangażowania innych, abyśmy sami mogli być chronieni. 
Promowanie to dawanie zachęt, otwieranie możliwości i pokładanie ufności $w$ możliwości każdego człowieka. Wiemy, że bez nadziei pokładanej w bliźnim i wraz z bliźnim, gdy od bliźniego nie oczekujemy wiele, nasze odczucia i poziom uznania jest niewłaściwy. Zasada wzajemnej zachęty stanowi, że każdy człowiek ma swoją treść, którą wnosi do społeczeństwa; jest to treść niepowtarzalna, której nigdy wcześniej nie słyszeliśmy.

Integrowanie to uznanie, że drugi człowiek, który przybył z prośbą o gościnę, jest członkiem naszej ludzkiej społeczności, należy do ciała Chrystusowego. Integrowanie nie polega na odmowie przyjęcia czy na zaprzeczaniu określonym cechom kulturowym, religijnym czy duchowym. Polega natomiast na dawaniu sobie nawzajem talentów i doświadczeń. Wzajemność przybiera tu najwyższą z form, bowiem integrowanie otwiera nas na wyzwolenie i zgodę, zarówno w obrębie naszej konkretnej społeczności, jak i w całej wspólnocie ludzkiej.

W tym tkwi wyzwanie nowego Przymierza w Jezusie Chrystusie w przebiegu naszej historii: chodzi o wzajemną gościnność, czyli doświadczenie wzajemnego przyjmowania i stawania się wspólnotą w Chrystusie.

\section{Bibliografia}

Franciszek (2018), Orędzie na Światowy Dzień Pokoju 2018, http://www.vatican.va/content/ francesco/en/messages/peace/documents/papa-francesco_20171113_messaggio51giornatamondiale-pace2018.html 03.06.2020.

Jan XXIII (1963), Encyklika Pacem in terris, http://www.vatican.va/content/john-xxiii/en/ encyclicals/documents/hf_j-xxiii_enc_11041963_pacem.html 02.06.2020.

Jan Paweł II (1987), Encyklika Sollicitudo rei socialis, http://www.vatican.va/content/ john-paul-ii/en/encyclicals/documents/hf_jp-ii_enc_30121987_sollicitudo-reisocialis.html 01.06.2020.

Moltmannn J. (1980), The Church in the Power of the Spirit: A Contribution to Messianic Ecclesiology, SCM, London. 